\title{
Correlation Studies on Seed Quality, Pod and Seed Yield in Germplasm of Pea (Pisum sativum L.)
}

\author{
Abhishek Panwar ${ }^{1 *}$, A. C. Mishra ${ }^{2}$ and Shivangi Negi ${ }^{1}$ \\ ${ }^{1}$ Dept. of Seed Science and Technology, ${ }^{2}$ Department of Vegetable Science, VCSG Uttarakhand University of Horticulture and \\ Forestry, Bharsar, Uttarakhand, (249 199) India
}

\section{Corresponding Author}

Abhishek Panwar

e-mail: jackpanwar@gmail.com

\author{
Article History \\ Article ID: 3 C0753 \\ Received in $29^{\text {th }}$ October, 2017 \\ Received in revised form $17^{\text {th }}$ December, 2017 \\ Accepted in final form $24^{\text {th }}$ January, 2018
}

\begin{abstract}
The present investigation was carried out during Rabi, 2014 at Research Block, Department of Crop Improvement, V. C. S. G. Uttarakhand University of Horticulture and Forestry, College of Forestry, Ranichauri Campus with 16 genotypes of vegetable pea (Pisum sativum L.) including released commercial cultivars and elite lines developed from different Institutes of India. With view to find out relationship of seed viability and seedling vigour parameters with field performance of the genotypes, the crops of all genotypes were raised in Randomized Block Design with three replications. The experimental crops were raised using recommended cultural operations for this region. Observations were recorded for days to $50 \%$ flowering, plant height at $50 \%$ flowering, number of pods plant ${ }^{-1}$, pod length, pod diameter, number of seeds pod $^{-1}, 10$ pod weight, pod yield plant ${ }^{-1}$ and seed yield plant ${ }^{-1}$. Correlation studies showed pod yield per plant was positively and significantly correlated with standard germination (0.807), seed vigour index-II (0.654), seedling fresh weight (0.600) and seedling dry weight (0.597). Seed yield plant ${ }^{-1}$, highly significant and positive correlation was observed with seed vigour index-II (0.392) and seedling dry weight (0.390). It is evident that prior estimation of standard germination, seedling dry weight and seedling vigour index-II of the seed lot in any genotype could be used to predict the yield potentiality of that genotype in open field conditions and the genotypes with higher values for these seed traits could be assumed to give higher pod and seed yield.
\end{abstract}

Keywords: Correlation, genotypes, germination, pea, vigour

\section{Introduction}

Pea (Pisum sativum L.) one of the most important annual legume crop of India, belongs to the Family Leguminousae (Fabaceae). Cytologically, it has $2 n=2 x=14$. There are two sub species, namely Pisum sativum var. arvense known as field pea, having colored flowers and Pisum sativum var. sativum, the white flowered garden pea, is largely confined to cooler temperate zone between the Tropic of Cancer and Mediterranean region. Being a cool season crop, it is most extensively grown in the temperate region throughout the world. Pea can be grown successfully during mid-summer and early fall in those areas having relatively low temperature and good rainfall or where irrigation is practiced. For very early crop, sandy loam is preferred, for higher yield where earliness is not a factor, a well-drained clay loam or silt loam is preferred (Duke, 1981). As a component of pulses, field pea supply major share for protein requirement of our country and per capita availability of pulses. But the area under pea production in India likely to be stagnating due to competition of irrigated wheat and other pulses with wider consumer use (Govardhan et al., 2013). For achieving future improvement, there is a great need to develop high yielding cultivars. The plant breeder depends upon variability present in the material for the improvement of quantitative and qualitative characters and their mutual association with seed yield (Tiwari and Lavanya, 2012; Kosev, 2014).

Pea is a rich source of dietary protein and also a valuable animal feed, being a leguminous crop it play a key role in improving and sustaining soil productivity on account of biological $\mathrm{N}_{2}$ fixation and addition of huge amount of organic matter.

The edible green pod contains $7.2 \%$ protein, $15.9 \%$ carbohydrate and $0.1 \%$ fat in $100 \mathrm{~g}$ of fresh pod. It is also an excellent source of minerals such as potassium $(170.0 \mathrm{mg})$, phosphorus (139.0 mg), calcium (20.0 mg), magnesium (6.0 $\mathrm{mg}$ ) and iron $(1.5 \mathrm{mg})$ per $100 \mathrm{~g}$ of green edible seed. The mature grain may be used as whole or prepared in various ways for human consumption. Pea has adequate amount of carotene $(83 \mu \mathrm{g})$, vitamin C $(9 \mathrm{mg})$, thiamine $(0.25 \mathrm{mg})$ and riboflavin $(0.01 \mathrm{mg})$ per $100 \mathrm{~g}$ of edible portion. Beside, pea contains all essential indispensable amino acids required in human foods (Choudhary, 2003). 
Being a cool season crop, it is most extensively grown in the temperate regions throughout the world. In tropics and subtropics, its cultivation is restricted to higher altitude and winter season. In India, annual production of vegetables is 162.187 million $\mathrm{mt}$ from the area $9.205 \mathrm{mha}$. Pea contributes 4.006 million $\mathrm{mt}$ production from the area of $0.4082 \mathrm{mha}$ in the country and productivity is $8.9 \mathrm{mt} \mathrm{ha}^{-1}$. In Uttarakhand, pea is grown on an area of 0.11 mha with an annual production of 0.078 million mt (Anonymous, 2014).

High quality seed is essential and desirable to ensure good crop establishment. For many field crops, one of the main problems observed is poor crop stand establishment of which is influenced by seed quality, adverse climatic condition, poor field management etc. (Maiti et al., 2002). At present a number of early maturing and high yielding varieties of pea have been recommended for plains, but the varieties for hilly regions are relatively few. In order to get high returns in terms of production and productivity, the selection of appropriate location specific cultivars is indispensible. This necessitates the evaluation and characterization of germplasm. Therefore, the present study has been conducted to derive information on superior genotypes based on their seed quality test by conducting field experiment.

\section{Materials and Methods}

The present investigation was carried out during the Rabi season of 2014-15 at Vegetable Research Block of Department of Vegetable Science, Veer Chandra Singh
Garhwali Uttarakhand University of Horticulture and Forestry, Ranichauri Campus, Tehri Garhwal, Uttarakhand with 16 genotypes of vegetable pea (Pisum sativum L.) including released commercial cultivars and elite lines developed from different Institutes of India. With view to find out relationship of seed viability and seedling vigour parameters with field performance of the genotypes, the crops of all genotypes were raised in Randomized Block Design with three replications. The experimental crops were raised using recommended cultural operations for this region. Observations were recorded for days to $50 \%$ flowering, plant height at $50 \%$ flowering, number of pods plant ${ }^{-1}$, pod length, pod diameter, number of seeds pod $^{-1}, 10$ pod weight, pod yield plan ${ }^{-1}$ and seed yield plant ${ }^{-1}$. The experiment was laid out in Randomized Complete Block Design with three replications.

\section{Results and Discussion}

\subsection{Correlation coefficients of pod yield and seed yield plant ${ }^{-1}$} with Seed quality characters

The assessment of seed viability and vigour traits by growing the seed samples of different genotypes in the laboratory condition before sowing in main field and further estimation of performance in field conditions enables to establish relationship between seed quality parameters and field performance. With the help of such relations, the potentiality of seed lot of a genotype could be assumed in advance. The estimates of correlation coefficients among different pairs of characters have been presented in Table 1.

Table 1: Estimates of correlation coefficients between seed yield and pod yield per plant with seed quality characters in vegetable pea genotypes

\begin{tabular}{llllllllllll}
\hline Characters & SG & RL & SL & SL $^{*}$ & SFW & SDW & VI-I & VI-II & SW & SYP & PYP \\
\hline First count (\%) & $0.435^{*}$ & -0.093 & 0.027 & -0.051 & $0.432^{*}$ & -0.083 & 0.021 & 0.006 & $-0.577^{*}$ & -0.051 & 0.177 \\
Standard germination (\%) & & 0.285 & -0.087 & 0.152 & $0.749^{* *}$ & $0.659^{* *}$ & 0.302 & $0.742^{* *}$ & -0.302 & 0.283 & $0.807^{* *}$ \\
Root length (cm) & & & $0.642^{* *}$ & $0.944^{* *}$ & $0.362^{*}$ & $0.464^{*}$ & $0.952^{* *}$ & $0.456^{*}$ & 0.265 & 0.188 & 0.330 \\
Shoot length (cm) & & & & $0.859^{* *}$ & $0.382^{*}$ & 0.108 & $0.818^{* *}$ & 0.092 & 0.026 & -0.266 & -0.098 \\
Seedling length (cm) & & & & & $0.406^{*}$ & 0.356 & $0.988^{* *}$ & 0.344 & 0.188 & 0.010 & 0.178 \\
Seedling fresh weight (g) & & & & & $0.612^{* *}$ & $0.504^{* *}$ & $0.665^{* *}$ & -0.306 & 0.015 & $0.600^{* *}$ \\
Seedling dry weight (g) & & & & & & $0.446^{*}$ & $0.992^{* *}$ & 0.053 & $0.390^{*}$ & $0.597^{* *}$ \\
Vigour Index-I & & & & & & & & $0.448^{*}$ & 0.136 & 0.053 & 0.295 \\
Vigour Index-II & & & & & & & & & -0.019 & $0.392^{*}$ & $0.654^{* *}$ \\
100 seed weight (g) & & & & & & & & & -0.082 & -0.082 & -0.051 \\
\hline
\end{tabular}

SG: Standard germination (\%); RL: Root length (cm); SL: Shoot length (cm); SL*: Seedling length (cm); SFW: Seedling fresh weight(g); SDW: Seedling dry weight (g); VI: Vigour index-I; VI-II: Vigour index- II; SW: 100 seed weight (g); SYP: Seed yield plant $^{-1}(\mathrm{~g})$; PYP: Pod yield plant ${ }^{-1}(\mathrm{~g})$; $^{*}$ Significant at $(p=0.05)$ level; ** Significant at $(p=0.01)$ level

The results on correlation studies showed that seed yield plant $^{-1}$ exhibited highly significant and positive correlation with seed vigour index-II (0.392) and seedling dry weight (0.390) whereas it established positive but non-significant association with standard germination (0.283) and root length (0.180). Pod yield per plant, positive and significant relation of it was found with standard germination (0.807), seed vigour index-II (0.654), seedling fresh weight $(0.600)$ and seedling dry weight 
(0.597). It appeared from such type of inter-relationships that the genotypes exhibiting high values for standard germination, seed vigour index-II and seedling fresh and dry weight, could be assumed to have high pod as well as seed yield per plant. Corroborating the findings of present investigation, high positive correlation of seed vigour index, seedling dry weight and standard germination with seed yield per plant have also been reported by Kumar (2007); Pant (2008); Prasad (2009), Shukla et al. (2009); Basaiwala et al. (2013) in vegetable pea.

Positive and significant correlation was noted for seedling vigour index-I with seedling length (0.988), root length (0.952), shoot length $(0.818)$, seedling fresh weight $(0.504)$ and seedling dry weight (0.446). Similarly, positive and significant association was also recorded for seedling vigour index-II with seedling dry weight (0.992), standard germination (0.742), seedling fresh weight (0.665), root length (0.456) and seedling vigour index-I (0.448). The 100 seed weight showed significant and negative correlation with first count $(-0.577)$ and the rest of character pairs had non-significant association. From the above results it is evident that prior estimation of standard germination, seedling dry weight and seedling vigour index-II of the seed lot any genotype could be used to predict the yield potentiality of that genotype in open field conditions and the genotype with higher values for these seed traits could be assumed to give higher pod and seed yield.

\subsection{Correlation coefficients of pod yield and seed yield plant ${ }^{-1}$ with attributing characters}

The estimates of correlation coefficients among different pairs of characters give an idea of trends of influence of one trait over the other. Such type of information is useful in explaining the causes behind an occurrence. The trends of relationship are also useful for pea breeders to predict possible performance of a population generated through indirect selection.

The results depicted in Table 2 showed that pod yield per plant was significantly and positively correlated with number of pods per plant (0.919), pod length (0.581) and 10 pod weight $(0.427)$ while it showed negative and significant correlation with pod diameter (-0.477). It indicated that high

Table 2: Estimates of correlation coefficients of pod yield and seed yield plant ${ }^{-1}$ with attributing characters in vegetable pea genotypes

\begin{tabular}{|c|c|c|c|c|c|c|c|c|}
\hline Characters & $\begin{array}{l}\text { Plant } \\
\text { height at } \\
50 \% \text { flow- } \\
\text { ering }(\mathrm{cm})\end{array}$ & $\begin{array}{l}\text { No.of pod } \\
\text { plant }^{-1}\end{array}$ & $\begin{array}{l}\text { Pod } \\
\text { length } \\
(\mathrm{cm})\end{array}$ & $\begin{array}{l}\text { Pod di- } \\
\text { ameter } \\
(\mathrm{mm})\end{array}$ & $\begin{array}{c}\text { No. of } \\
\text { seeds } \\
\text { per pod }\end{array}$ & $\begin{array}{c}10 \text { pod } \\
\text { weight }(\mathrm{g})\end{array}$ & $\begin{array}{l}\text { Pod } \\
\text { yield } \\
\text { plant }^{-1} \\
\text { (g) }\end{array}$ & $\begin{array}{c}\text { Seed } \\
\text { yield } \\
\text { plant }^{-1} \\
\text { (g) }\end{array}$ \\
\hline Days to $50 \%$ flowering & -0.099 & -0.083 & 0.212 & -0.201 & -0.183 & -0.179 & -0.125 & 0.264 \\
\hline $\begin{array}{l}\text { Plant height at } 50 \% \text { flow- } \\
\text { ering }(\mathrm{cm})\end{array}$ & & -0.195 & $-0.569^{* *}$ & $0.555^{* *}$ & 0.082 & -0.264 & -0.285 & 0.206 \\
\hline Number of pods plant ${ }^{-1}$ & & & $0.489^{*}$ & $-0.437^{*}$ & -0.046 & 0.057 & $0.919^{* *}$ & $0.366^{*}$ \\
\hline Pod length $(\mathrm{cm})$ & & & & $-0.384^{*}$ & 0.359 & 0.307 & $0.581^{* *}$ & 0.344 \\
\hline Pod diameter (mm) & & & & & 0.223 & -0.147 & $-0.477^{*}$ & -0.035 \\
\hline Number of seeds pod ${ }^{-1}$ & & & & & & $0.644^{* *}$ & 0.206 & $0.403^{*}$ \\
\hline 10 pod weight (g) & & & & & & & $0.427^{*}$ & -0.055 \\
\hline Pod yield plant ${ }^{-1}(\mathrm{~g})$ & & & & & & & & 0.306 \\
\hline
\end{tabular}

pod yield in vegetable pea could be achieved by practicing selection for number of pods plant ${ }^{-1}$, pod length and 10 pod weight whereas the genotypes with more pod diameter should be discouraged. Corresponding to the results of present investigation, Singh et al. (2008); Nawab et al. (2008); Jitender et al. (2010); Ghobary (2010); Pal and singh et al. (2012). have also reported positive and significant association of pod yield plant ${ }^{-1}$ with number of pods plant ${ }^{-1}$, pod length and pod weight. Seed yield plant ${ }^{-1}$ was positively and significantly correlated with number of seeds per pod (0.403), number of pods plant ${ }^{-1}(0.366)$ and pod length (0.344). It is evident that selection for number of pods plant ${ }^{-1}$ and pod length would lead to simultaneous improvement in pod yield plant ${ }^{-1}$ and seed yield plant ${ }^{-1}$ both in vegetable pea. Significant positive correlation of number of pods plant ${ }^{-1}$ and high but non-significant positive value of number of seeds per pod was also reported by Ghobary (2010) in vegetable pea. From the correlation between pod and seed yield attributing characters, it could be summarized that number pods plant ${ }^{-1}$ and pod length were the principal traits contributing to pod and seed yield and practicing selection for these traits would lead to simultaneous improvement in pod and seed yield both in garden pea.

\subsection{Correlation coefficients between yield attributing and seed quality characters}

The studies on correlation between seed vigour and viability parameters and seed and pod yield attributing traits would facilitate to predict the trend of increase or decrease in the value of traits appearing field on the basis of laboratory testing 
of vigour and viability parameters. The results depicted in Table 3 showed that as far as relationship between these set of parameters is concerned, seedling dry weight was positively and significantly correlated with days to $50 \%$ flowering (0.376). Plant height at 50\% flowering however, established negative and significant association with most of vigour and viability traits viz., seedling vigour index-I $(-0.555)$, seedling length $(-0.518)$, seedling fresh weight $(-0.509)$, root length $(-0.491)$, shoot length (-0.442) and standard germination (-0.405). It indicated that plant height was highly affected by the environmental conditions and there was unparallelism in seed and seedling vigour of laboratory and field vigour. However, in contrary to the results of present investigation Guleria et al. (2009) , Prasad (2009) and Shukla et al. (2009) noticed positive association of plant height with most of seed and seedling vigour parameters in vegetable pea.

\begin{tabular}{|c|c|c|c|c|c|c|c|}
\hline Characters & $\begin{array}{c}\text { Days to } \\
50 \% \text { flower- } \\
\text { ing }\end{array}$ & $\begin{array}{c}\text { Plant height } \\
\text { at } 50 \% \\
\text { flowering }\end{array}$ & $\begin{array}{l}\text { No. of pod } \\
\text { plant }^{-1}\end{array}$ & $\begin{array}{l}\text { Pod } \\
\text { length } \\
(\mathrm{cm})\end{array}$ & $\begin{array}{l}\text { Pod diam- } \\
\text { eter ( } \mathrm{mm} \text { ) }\end{array}$ & $\begin{array}{l}\text { No. of } \\
\text { seeds } \\
\text { pod }^{-1}\end{array}$ & $\begin{array}{c}10 \text { pod } \\
\text { weight (g) }\end{array}$ \\
\hline First count (\%) & -0.171 & -0.176 & 0.060 & 0.282 & -0.213 & 0.222 & 0.281 \\
\hline Standard germination (\%) & 0.035 & $-0.405^{*}$ & $0.745^{* *}$ & $0.480^{*}$ & $-0.559^{* *}$ & 0.090 & 0.324 \\
\hline Root length $(\mathrm{cm})$ & -0.052 & $-0.491^{*}$ & $0.424^{*}$ & $0.478^{*}$ & $-0.460^{*}$ & 0.044 & -0.113 \\
\hline Shoot length $(\mathrm{cm})$ & -0.006 & $-0.442^{*}$ & -0.076 & 0.353 & -0.318 & 0.066 & -0.108 \\
\hline Seedling length $(\mathrm{cm})$ & -0.037 & $-0.518^{* *}$ & 0.250 & $0.471^{*}$ & $-0.444^{*}$ & 0.058 & -0.122 \\
\hline Seedling fresh weight (g) & 0.095 & $-0.509^{* *}$ & $0.540^{* *}$ & $0.534^{* *}$ & $-0.574^{* *}$ & 0.067 & 0.297 \\
\hline Seedling dry weight (g) & $0.376^{*}$ & -0.195 & $0.696^{* *}$ & $0.486^{*}$ & -0.354 & -0.073 & -0.041 \\
\hline Vigour Index-I & -0.028 & $-0.555^{* *}$ & 0.358 & $0.527^{* *}$ & $-0.509^{* *}$ & 0.071 & -0.075 \\
\hline Vigour Index- II & 0.353 & -0.237 & $0.729^{* *}$ & $0.520^{* *}$ & $-0.399^{*}$ & -0.044 & 0.012 \\
\hline 100 seed weight (g) & -0.255 & 0.250 & 0.045 & $-0.362^{*}$ & $0.369^{*}$ & 0.070 & 0.055 \\
\hline
\end{tabular}

\section{Conclusion}

An overview of the experimental results of present investigation indicated a wide spectrum of variation with respect to morphological and seed quality parameter among all the sixteen genotypes of vegetable pea. Correlation coefficients depicts that prior estimation of standard germination, seedling dry weight and seedling vigour index-II of the seed lot in any genotype could be used to predict the yield potentiality of that genotype in open field conditions.

\section{References}

Anonymous, 2014. Area and Production of vegetable crops 2013-14 (2 ${ }^{\text {nd }}$ Advance Estimates). www.nhb.org.in.

Basaiwala, P., Rastogi, N.K., Parikh, M., 2013. Genetic variability and character association in field pea (Pisum sativum L.) genotypes, Asian Journal of Horticulture 8(1), 288-291.

Choudhary, V., 2003. Vegetable, National Book Trust New Delhi, 230p.

Duke, J.A., 1981. Hand Book of Legumes of World Economic Importance. Plenum Press, New York, 199-265.

Ghobary, H.M., 2010. Study of relationship between yield and some components in garden pea (Pisum sativum L.) by using correlation and path analysis. Journal of Agriculture Research 36, 351-360.

Govardhan, G., Lal, G.M., Vinoth, R., Ashok Reddy, P., 2013.
Character association studies in $\mathrm{M} 2$ generation of field pea (Pisum sativum var. arvense L.). International Journal of Applied Biology and Pharmaceutical Technology 4(4), 161-163.

Guleria, Sonali, Chongtham Nirmala and Dua Saroj (2009). Genetic variability, correlation and path analysis studies in pea (Pisum sativum L.). Crop Research (Hisar) 38(1/3), 179-183.

Jitendra, K., Ashraf, N., Pal, K., 2010. Variability and association in garden pea (Pisum sativum L. sub sp. hortense Asch and Graebn). Progressive Agriculture 10(1), 124-131.

Kosev, V., 2014. Breeding and Genetic Assessment of some quantitative traits in crosses forage pea (Pisum sativum L.). Open Journal of Genetics 4, 22-29.

Kumar, V., 2007. Studies on seed quality parameter in diffrent pea (Pisum sativum L.) genotypes under hill condition. M.Sc. Thesis submitted to G.B. Pant University of Agriculture and Technology, Pantnagar, Uttarakhand, India, 127.

Maiti, R.K., Mooreno-Limon, S., 2002. Seed and seedling traits in french bean (Phasiolus vulgaris) and its relation to abiotic stress resistance. Legume Research 24, 211-221.

Nawab, N.N., Subhani, G.M., Khalid Mahmood Qamar and Shakil Akhtar Saeed (2008). Genetic variability, correlation and path analysis studies in garden pea (Pisum sativum L.). Journal of Agricultural Research (Lahore) 46(4), 333-340. 
Pal, A.K., Singh, S., 2012. Correlation and path analysis in garden pea (Pisum sativum L. var. Hortense). Asian Journal of Horticulture 7(2), 569-573.

Pant, M., 2008. Studies on morphological and seed quality parameters of vegetable pea (Pisum sativum L.). M.Sc. Thesis submitted to G.B. Pant University of Agriculture and Technology, Pantnagar, Uttarakhand, India, 43-55.

Prasad, S., 2009. Effect of moisture stress on germination and seedling growth of vegetable pea (Pisum sativum L.). M.Sc. Thesis submitted to G.B. Pant University of Agriculture and Technology, Pantnagar, Uttarakhand, India, 48-74.
Shukla, P.S., Kumar, A., Prasad, S., 2009. Correlation Analysis of Seed Yield and Vigour Parameters of Vegetable Pea Varieties under Moisture Stress Condition. Trends in Biosciences 2(1), 65-66.

Singh, V.K., Srivastava, C.P., Chand, R., Singh, A.K., Singh, K.K., 2008. Variability studies for yield and its contributing characters and aupic in pea (Pisum sativum). Vegetable Science 35(1), 38-40.

Tiwari, G. and Lavanya, G.R., 2012. Genetic variability, character association and component analysis in F4 generation of field pea (Pisum sativum var. arvense L.). Karnataka Journal of Agricultural Sciences 25, 173-175. 